\title{
Income Diversification and Economic Welfare of Rural Households in the Volta Region of Ghana
}

\author{
Kwabena Asomanin Anaman ${ }^{1} \&$ Kinsley Delanyo Adjei ${ }^{1}$ \\ ${ }^{1}$ Department of Agricultural Economics and Agribusiness, College of Basic and Applied Sciences, University of \\ Ghana, Legon, Accra, Ghana
}

Correspondence: Professor Kwabena Asomanin Anaman, Department of Agricultural Economics and Agribusiness, College of Basic and Applied Sciences, University of Ghana, Legon, Accra, Ghana.

Received: September 28, 2020

Accepted: November 5, 2020

Online Published: January 6, 2021

doi:10.5430/rwe.v12n1p120

URL: https://doi.org/10.5430/rwe.v12n1p120

\begin{abstract}
We established the factors influencing income diversification, and the linkage between income diversification and economic welfare of rural households, in the Volta Region of Ghana, using data from 894 randomly-selected households, obtained through the latest round of the Ghana Living Standards Survey undertaken by the Ghana Statistical Service from October 2016 to October 2017. The overall household income diversification, measured by the Simpson Index was positively influenced by the age of the household head, remittances received by the household, and the size of the household. Using another measure of diversification, the number of income-based activities (NIBA), we established that the age of the household head influenced NIBA in a cubic fashion, similar to an S-shaped curve. Income diversification declined at very young ages from 17 to 31 years; it then increased from 31 years to 74 years before declining during the household head's advanced age and retirement period. The positive drivers of NIBA included moderate levels of formal educational attainment, remittance, household size and electricity connection. We showed that income diversification influenced economic welfare only when used at moderate to high levels.
\end{abstract}

Keywords: diversification, economic welfare, Ghana, income diversification, poverty, sustainable development

\section{Introduction and Problem Statement}

\subsection{Background}

Economic welfare is related to a status where a person can reach his/her potential ability based on his/her talents, and is able to construct a solid and positive relationship with other human beings, thus contributing to the advancement of the community and the nation. Welfare is improved when a person can fulfill his/her individual and social objectives and goals in society (Aked et al., 2008). Sustainable livelihood and household welfare are intertwined and these two concepts are at the heart of rural development efforts made by policymakers in many countries.

As a country's gross domestic product (GDP) grows, the share of the GDP attributed to the agricultural sector declines. Yet, the proportion of the labour workforce that depends on the agricultural sector, as their major source of livelihood, does not decline as fast as the drop in the share of GDP attributed to the agricultural sector. This means that many rural people continue to depend on farming and related occupations while the general economy expands in the direction of the industrial and services sectors. The growth in the industrial and services sectors of the economy is not divorced from the growth of the agricultural sector (Chenery \& Syrquin, 1975). As shown by the Covid-19 pandemic affecting many countries, the resilience of the agricultural sector is stronger than that of the industrial and services sectors.

The recent ranking of Ghana (2020) on the United Nations Human Development (UNDP) Index Scale is number 138 out of a total 189 countries (UNDP, 2020) suggesting that Ghana is a low-to-modest performer in terms of human development. The average per capita gross domestic product (GDP) of Ghana in 2020 was about 2,124 United States dollars (US\$) using the latest estimates produced by the Ghana Statistical Service (GSS). This GDP per capita level puts the country into the lower-middle-income country category. The economy of Ghana, as measured by annual changes in GDP grew continuously over the 36-year period from 1984 to 2019, fluctuating from a low of 2.2\% to $14 \%$, mostly above the average annual population growth rate of $2.3 \%$. This economic growth was associated with 
extensive environmental destruction, fast growth of income inequality, and increasingly higher shares of national income going to owners of human-made capital (Anaman and Bukari, 2021).

A measure of income inequality is the Gini coefficient. The income Gini coefficient of Ghana increased from 41.9 in 2006 to 42.3 in 2013 and then to 43.0 in 2017 (GSS, 2018, p. 23). The increasing income inequality has placed a bigger burden on members of small tribes. This inequality is linked to the inadequate allocation of government administrative districts and public services for areas inhabited by members of small tribes (Anaman and Bukari, 2021).

\subsection{Problem Statement}

The agriculture sector is the major employment of rural people in Ghana. The sector contributed about $20 \%$ of Ghana's GDP over the 2013-2019 period (GSS, 2020). It employs about 42\% of people in the country, who are mostly small landholders (GSS, 2013). Agriculture is the prevailing source of income for many rural households in Ghana where poverty remains persistently high. Non-farm sources of income generation provide additional avenues to rural householders to tackle poverty. An issue that arises in the development discourse is the willingness of policymakers to support non-agricultural activities without reducing farm productivity or food sufficiency.

Prior to January 2019, and during the implementation of all seven Ghana Living Standards Surveys, (GLSS) from 1992 to 2017, Ghana had 10 politically administrative regions. Volta Region, the area of this study, is one out of the five regions that were considered to have had extreme poverty incidence based on a trend analysis of Ghanaian poverty rates using GLSS data from 2005 to 2017, related to the fifth, sixth and seventh rounds of the GLSS (GSS, 2008, 2014, 2018). The incidence of poverty in the Volta Region was higher than the national average (GSS, 2018).

Poverty is defined as the lack of basic necessities such as water and food, shelter, education, medical care and security that all human beings must have. Often poverty is measured by per capita expenditure. In Ghana, the GSS formally defined the upper poverty level as the average adult householder being unable to spend 1760.80 Ghana cedis per year or 4.82 Ghana cedis per day in 2016/2017 (GSS, 2018, pp. 8-9). The lower poverty line (extreme poverty) was 982.2 Ghana cedis per adult person equivalent per year or 2.69 Ghana cedis per adult person equivalent per day in 2016/2017.

Using the international benchmark figure developed by the World Bank of the poverty line being 1.90 United States (US) dollars per adult person per day based on 2015 economic baseline, the adjusted poverty line (using United States annual inflation rate) would be US\$ 1.96 dollars per adult person per day or 8.22 Ghana cedis (GHS) based on an average exchange rate of 4.21 GHS to one US\$ (2016/2017 figures). Using this international benchmark figure, the poverty rate in rural Volta Region was estimated in this study to be $64.1 \%$ for the period, 2016/2017.

The high poverty rate could be a driver of several secessionist movements which have sprung up in the Volta Region, such as the Homeland Study Group Foundation (HSGF). The HSGF is a member of the Unrepresented Nations and Peoples' Organization (UNPO), founded in 1991 at The Hague, Netherlands. UNPO acts as a voice of marginalized peoples and tribes around the world. In November 2019, the HGSF formally declared the Western Togoland (which includes the Volta Region) as a separate country from Ghana.

Effective policy actions to reduce poverty would require accurate information from evidence-based research that analyses livelihood activities of householders, including the linkages between income diversification and poverty reduction. Hence the objective of this study was to establish the scale of income diversification, the factors influencing income diversification, and the linkage between income diversification efforts and household economic welfare of rural households in the Volta Region of Ghana using GLSS7 data. The rest of the paper is organized as follows: the next section is the review of the literature. This is followed by the presentation of the methods and procedures used in the study, the results of the analysis, the conclusions and policy recommendations, and a list of cited references.

\section{Literature Review}

\subsection{Introduction}

According to Davis et al. (2007) rural income is classified into two simple groups: agricultural and non-agricultural incomes. However, Ellis (2000) classifies rural income into three types: farm, off-farm, and non-farm incomes. Farm income is obtained from the household's farming activities; this income includes earnings from both crop and livestock production, fisheries and harvesting of forest products. Off-farm income is the income generated from wages or exchange of labour by householders working on different farms; this particular income is still derived from working on farms or in the agricultural sector. Non-farm income comes from non-agricultural activities, and is 
derived from householders working for wages in non-farm activities, remittances from other family members and members of the household's social network, and non-farm entrepreneurship activities. The GSS has consistently classified income sources in Ghana into six broad groups. These six groups are (1) agriculture, (2) wage-based sources, (3) non-farm enterprises, (4) rental income, (5) remittances, and (6) all other sources of income.

Welfare or wellbeing can be expressed in terms of an individual's appreciation of positive feelings of joy and satisfaction. It is also expressed on a scale of positive to negative as it relates to one's self-worth or esteem. Wellbeing is characterized by one's present standard of living, deficiencies in standard of living, or a combination of both (Pollard \& Lee, 2003). It stems from the degree of fit between an individual's recognition of his/her conditions and his/her desires or values (Andrew \& Withey, 1976). There are two components of wellbeing: material wellbeing (sometimes called economic welfare), and social wellbeing.

Material wellbeing is indicated through the individual's possession of material goods and services which make living comfortable. Linked to the possession of material goods and services, material wellbeing requires good health, being in the correct state of mind, and physical fitness. Social wellbeing includes variables such as belonging to a family or close-knit group, harmony and good affinity with others in the community, including undertaking compassionate activities, and a general sense of safety and security within the household and the community. Social well-being then implies peace of mind at home and work, favorable environment, personal and physical security. It also involves having flexible choices in balancing work and leisure activities, and the ability to undertake activities that help other people and society in general as suggested by Narayan et al. (2000).

\subsection{Concept of Income Diversification and Related Empirical Works}

Income diversification is the process by which income-generating sources are spread to increase their average returns from investment while minimizing overall risks. Income diversification of a household can be envisioned as a portfolio of activities. The number of activities in the portfolio is related to the householder's perceptions of the average returns of activities and his/her willingness to bear the risks involved in production of activities within the portfolio.

According to Rønning and Kolveried (2006), income diversification involves deriving income from both farm and non-farm sources. Ellis (2000) argues that household income diversification plays a vital role in poverty alleviation since it offers alternative employment, productivity, and income apart from farming. The interaction between agricultural inputs such as fertile land, good climate, sufficient rainfall, labour force, and closeness to market centres, help in determining locational opportunities, occupational choices, and greater incomes from economic activities.

In Sub-Saharan Africa, farmers generally have small holdings arising from the fragmentation of land parcels related to a fast-growing population. There is a relatively low level of the use of modern inputs such as fertilizers and irrigation equipment, which also tend to be imported. Further, income diversification policies tend to help the better-off households who are favored by their connections with the powerful and those placed at the top of the political power hierarchy (Loison, 2015). Haggblade et al. (2010) suggest that government income diversification programmes need to be more structured and highly targeted to meet the needs of more deserving rural households.

\subsection{Determinants of Income Diversification}

The determinants of income diversification have been investigated by a number of research workers. Salifu (2019) provides a more recent review of factors driving income diversification. Most rural households rely on farm activities as a major if not the biggest source of their income. Yet, farm income is often not sufficient for adequate economic welfare of many rural dwellers partly explaining the relatively high levels of poverty, especially in rural parts of Africa. Under many conditions, especially in areas with unimodal rainfall patterns, farmers tend to rely on seasonal farming, and need to find other sources of income to maintain the economic welfare of themselves and their families, when the farming season has ended (Salifu, 2019).

Rural income diversification deals with income-generating activities of rural householders, and who are often farmers, who are essentially private actors in market settings. Thus, rural income diversification is affected by factors such as the risk attitudes of individuals and market-based barriers and artificial hurdles that discriminate against people from participating in certain labour markets. The literature commonly classifies factors affecting rural income diversification into two groups as follows: "pull factors" and "push factors". The pull factors of income diversification are benefits from interrelated activities; new income sources created through market development, improvement in infrastructure, and diversification for asset accumulation.

For smallholder farmers, push factors are ex-ante risk management strategies (Hoogeveen, 2002). However, for Carter (1997) push factors for smallholder households are ex-post risk-coping strategies. Omamo (1998) suggests 
that income diversification is enforced by push factors such as high-transaction costs. Liquidity constraints, lack of lending market, and the seasonal activities of agricultural production are factors which push households to engage in non-farm activities. Building of markets and developing them is essential in encouraging households to redeploy their productive resources for higher-yielding activities. Push factors resulting from agricultural seasonality, regular climatic hazards, poor resources endowment, lack of finance to undertake a range of activities result in increased diversification.

Farmers with larger farm sizes diversified less into off-farm activities as compared to farmers with smaller farm sizes (Gecho, 2017). The sex of the household head could influence the degree and level of income diversification. Agyemang et al. (2014) showed that female-headed households engaged in both off-farm as well as on-farming activities; the increased scope of these joint activities influenced the degree and level of income diversification. Nevertheless, female-headed households tend to be poor and are more likely to be disproportionally represented in the poverty-stricken households group. Female-headed households are also not likely to change their strategy of diversification (Dedehouanou \& McPeak, 2020). Marriage is suggested as a source of new ways for income diversification outside the traditional dependence of income on males (see for example, Anaman and Kassim, 2006).

\subsection{Relationship Between Income Diversification and Household Economic Welfare}

Household consumption aggregate is the value of the flow of all consumption activities undertaken by household members. Economic welfare or wellbeing reflects the level of satisfaction from life, the health condition of an individual, capability or incapability, and constructive functioning in the society (Kahn \& Juster, 2002). Poverty enlarges the deprivations faced by householders. These deprivations include inadequate levels of income, food, and access to housing.

Income diversification offers householders an escape from poverty and the pursuit of goals that improve their well-being. Many countries use multiple measures to capture monetary and non-monetary well-being. The main cause of food insecurity and poor well-being is poverty. This is due to a lack of resources that enable householders to acquire sufficient nutritious food. The cost of living varies from one location to the other. Food items obtained from production and the size of the household determine the food security status of the farming household. As income diversification increases, it provides additional income that farmers can spend on their needs which include food, education, clothing, and health care.

\section{Methods and Procedures}

\subsection{Theoretical Framework of the Study}

The sustainable livelihood concept is the driving theoretical framework of this study. The concept was developed in the 1990s for the analysis of poverty (Scoones, 1998; Ellis, 2000; Cahn, 2002). It is employed to assess the vulnerability of a household and its ability to cope with shocks now or in the future and still maintain or enhance its total capital stock. This framework is useful to establish the potential ability of a household to undertake certain income-generating activities based on its total capital stock and limitations of various forms of capital inputs. This principle is based on the premise that a householder produces various forms of income from his/her portfolio of income-generating activities subject to the basic constraints of various capital inputs.

When householders are unable to generate adequate incomes, this results in human degradation which falls into the general malaise of human conditions that economists call "market failures". The corrections of market failures often involve an expanded role of State and Community institutions. The SL framework asserts that market failures, associated with rural households' inability to generate adequate incomes, are linked to the availability and inadequacies of various forms of capital inputs. These capital inputs are (1) Environmental and natural capital, (2) Human capital, (3) Physical capital, (4) Financial capital, (5) Social capital, and (6) Informational capital.

Environmental and natural capital includes land which may naturally be fertile or not; it al so includes the presence of pests which may destroy crops and livestock. Human capital inputs are the skills, knowledge, abilities, and capacities of human beings that also aid in the development of other capital inputs. Human capital inputs include schooling, specialist technical skills, and health status. Physical capital denotes inputs developed by human beings to produce goods and services that are in the form of machines, tools and equipment. Financial capital includes cash, credit and borrowed money which can be used to purchase goods and services required to produce other goods and services. Social capital involves the relationships and the networks that help household to cope with daily life and access inputs to produce livelihood activities. Finally, informational capital deals with inputs that allow householders to gather data and information from various outlets in order to produce, consume and exchange goods and services.

While the SL framework drives our study, we also argue that the productivity of capital inputs used to generate goods 
and services by the household is shaped and influenced by external factors such as natural shocks (for example, drought), government policies, communal conflict, discrimination related to artificial hurdles and barriers involving class, ethnicity, gender and religious dimensions, among others. For example, government policies can improve social infrastructure such as roads and electricity supply networks and aid in the production and marketing of goods.

\subsection{Measurement and Analysis of Income Diversification}

A common measure of income diversification is the Simpson index (SI) (Simpson, 1949). This measure is directly derived from the Herfindahl-Hirschman Index (HHI). The HHI was developed by Hirschmann (1945) and Herfindahl (1950). This index is obtained by squaring the share of income attributed to each asset or activity within the household portfolio of income-generating assets or activities, and summing up all these squares. The SI is simply 1-HHI, and it has a range of zero to one. The SI is considered to be both a "richness" and "evenness" measure as it establishes both the number of activities (richness), and the spread and importance of these activities (evenness) in the income-generating portfolio of the household. Given that the SI values can be zero, analysis involving the determinants of SI cannot be undertaken by standard multiple regression analysis. Specific maximum likelihood procedures, first developed by Tobin (1958), are often used to estimate SI functions (Salifu and Anaman, 2019).

The second common measure of diversification is the number of income-based activities (NIBA). NIBA is considered to be only a richness measure. Due to the count-nature of NIBA, the estimation of the determinants of NIBA (dependent variable) cannot be handled by standard multiple regression analysis, and is done using maximum likelihood procedures, often based on the Poisson and the negative binomial distributions. In this study, we used the Poisson distribution function procedure to estimate the NIBA regression equation.

\subsection{Definition of Variables Used in the Income Diversification Regression Models}

Twenty-four independent variables available from the GLSS7 dataset are used for the analysis of the factors influencing income diversification using Tobit and Poisson regression models. These variables are defined as follows:

HHAGE is the age of the household head in years; HHAGESQ is the squared value of HHAGE while HHAGECUBIC is the cubic form of HHAGE. The use of the three functional forms for the age of the household head is to analyse the reproductive life-cycle behavioural pattern with regards to income diversification and the age of the household head.

SEXHH is a dummy variable for the household head with 1 denoting a male-headed household and zero for a female-headed household. This variable is to ascertain any gender-based effects on income diversification.

CMARRIED is a dummy variable with 1 representing a household head currently married and zero otherwise. This variable is incorporated in the model to investigate whether marriage influences income diversification. The variable is an enhanced human capital input arising from the possible specialization and division of labour in the household which could enhance overall productivity and increase diversification.

DISABLED is a dummy variable for household head with 1 for disabled status and zero for able-bodied status. Disability status often reduces the capacity of a householder to fully engage in market-based activities leading to market failure and this could affect income diversification. This variable largely reflects reduced human capital input.

HHSIZE is the number of people in the household and this is adjusted for adult-equivalent number. The size of the household could affect income diversification; however its directional impact is not clear given the conflicting results reported in the literature (see Salifu, 2019).

EDPRIMARY is a dummy variable with 1 for household heads who completed several years of primary school education varying from one to six years.

EDJSS, EDSSS, EDPSTECH, EDUNIVERSITY and EDADULT are specific dummy variables for household heads who have acquired junior secondary school, senior secondary school, post-secondary technical college/vocational institute, university, and specialist adult education qualifications, respectively. These are human capital inputs.

PHONE is a dummy variable for ownership of mobile phone by the household head. This variable is considered to be informational capital input.

HOUSEOWN is a dummy variable for house ownership by the household. This variable is considered to be physical capital input.

RENTALVALUE is the economic value of the household dwelling based on equivalent annual rental value of the property and/or actual rents paid for tenants as household heads denoted in Ghana cedis (GHS). This variable could 
be considered to be a physical input variable.

REMIT is the annual amount of remittances received by the household from extended family members and social networks. This variable is a financial capital input.

ELECTRICITYCON is a dummy variable with a value of 1 if the household is connected to electricity supply often provided by the State electricity grid, and zero otherwise.

AFRITRADRELIGION is a dummy variable with a value of one if the household head is an adherent of various African Traditional Religions, and zero otherwise.

CHRISTIAN is a dummy variable for household heads practising various forms of Christianity.

ISLAM is a dummy variable for household heads who practice the Islamic Religion.

EWE, GUAN and GURMA are specific dummy variables for household heads belonging to the Ewe, Guan and Gurma broad ethnic groups respectively. Ghana has nine broad ethnic groups and 89 individual tribes (GSS, 2017; Anaman and Bukari, 2019). The three religious-affiliation and broad ethnicity group variables would represent "structures" that could act in a grouped-form to affect income diversification; this hypothesis is tested in the analysis.

\subsection{Measurement of Economic Welfare}

In order to compare households of different sizes, a Parametric Equivalence Scale (PES) was used to measure the economic welfare as indicated by the amount of consumption expenditure per adult equivalent. The PES adjusts the family size using Equation 1.

$$
\lambda=(\text { HHSIZE })^{\sigma}
$$

Where:

HHSIZE is the nominal household size and $\sigma$ is the scale relativity parameter.

In other to put the same weight on every member of the household, $\sigma$ is applied to the household size implying that every additional member will have the same income needs. Further, the relative needs of children are adjusted to the scale of adults considered to be those 17 and above.

The PES used in this study is denoted in Equation 2 with the scale relativity parameter of 0.725 . The 0.725 scale relativity parameter figure was the value that ensured that we obtained exactly the $23.4 \%$ average poverty rate for Ghana determined by GSS using the same GLSS7 dataset (GSS, 2018). Other researchers have used the relativity parameter figures ranging from 0.65 to 0.75 (Buse \& Salathe, 1978; Bellù \& Liberati, 2005; Sultana et al., 2015).

$$
\text { HEW }=\text { HHEXP/(HHSIZE) })^{0.725}
$$

Where HEW is household economic welfare, HHEXP is total household expenditure, HHSIZE is the nominal household size, and 0.725 is the scale relativity parameter that adjusts for adults.

\subsection{Analysis of the Linkage Between Income Diversification and Household Welfare}

A multiple regression model analysis was used to ascertain the relationship between income diversification and household economic welfare. The model is specified as Equation 3 below:

$$
\begin{array}{r}
\text { LHEW }=\mathrm{A}_{0}+\mathrm{A}_{1} \text { SI }+\mathrm{A}_{2} \text { SISQUARED }+\mathrm{A}_{3} \text { HHAGEGROUP }+\mathrm{A}_{4} \text { LARGEHHSIZE }+\mathrm{A}_{5} \text { EDPRIMARY }+\mathrm{A}_{6} \\
\text { EDSSS }+\mathrm{A}_{7} \text { EDPSTECHNICAL }+\mathrm{A}_{8} \text { EDUNIVERSITY }+\mathrm{A}_{9} \text { EDADULT }+\mathrm{A}_{10} \text { LRENTALVALUE }+\mathrm{A}_{11} \\
\text { ELECTRICITYCON }+\mathrm{A}_{12} \text { DISABLED }+\mathrm{A}_{13} \text { DISABLED } * \text { CMARRIED }+\mathrm{A}_{14} \text { DISABLED*HOUSEOWN }+\mathrm{A}_{15} \\
\text { AFRITRADRELIGION }+\mathrm{A}_{16} \text { CHRISTIAN }+\mathrm{A}_{17} \text { ISLAM }+\mathrm{A}_{18} \text { EWE }+\mathrm{A}_{19} \text { GUAN }+\mathrm{A}_{20} \text { GURMA }+\mathrm{U}(3)
\end{array}
$$

Where:

LHEW denotes the natural logarithm of household economic welfare defined as the total household expenditures divided by the adjusted household size, in terms of adult equivalence.

SISQUARED is the square of SI.

HHAGEGROUP is a dummy variable with a value of 1 if the household head is greater than 68 years (considered to be retired person), and zero of the household head is 68 years or younger. This variable is used as an instrumental variable for age as the original age variable is related to SDI; both variables could not be used in the same model due to the problem of endogeneity.

LARGEHHSIZE is a dummy variable with a value of 1 if the nominal household size is greater than five, and zero if the nominal household size is five or less. This variable is also used as an instrumental variable for household size as 
the latter variable is strongly related to SDI and both variables could not be used in the same model so as to avoid the problem of endogeneity. The choice of five is based on a numerical simulation analysis of household size from one to 19 which yields five as the optimal household size.

LRENTALVALUE is the natural logarithm of RENTALVALUE.

DISABLED*CMARRIED is an interaction term involving DISABLED and CMARRIED. This interaction term is a moderating variable, used to analyse the welfare of households headed by disabled people, and for which the head is currently married; this is to evaluate whether marriage could reduce the disability burden of the household.

DISABLED*HOUSEOWN is an interaction term involving DISABLED and HOUSEOWN. This combined term is also a moderating variable and is used to analyse the welfare of households headed by disabled people which own their dwelling premises; this interaction term evaluates the effect of house ownership on the disability burden.

$\mathrm{A}_{\mathrm{i}}$ (where $\mathrm{i}=0,1,2,3,4,5,6,7,8,9,10,11,12,13,14,15,16,17,18,19$ and 20) are parameters to be estimated; and $\mathrm{U}$ is the equation error term, initially assumed to have zero mean and constant variance. All the other variables used in Equation 3 have been defined earlier.

\subsection{Data and Data Sources}

Data used were obtained from GLSS7 and were restricted to the 894 rural sampled households in the Volta Region from a total sample of 14,009 households nationwide. The GLSS is a nationally-representative survey of households and individuals, designed along the lines of the World Bank's Living Standards Measurement Surveys. The GLSS7 sampling employed a two-stage stratified sampling design, and was undertaken from October 2016 to October 2017. The rural survey response rate in the Volta Region was 93.1\% (GSS, 2017, 2018).

\section{Results and Discussion}

\subsection{Socioeconomic Characteristics of the Sampled Rural Households}

Table 1 shows the summary information on the socioeconomic characteristics of 894 randomly selected households in the Volta Region of Ghana. About five out of eight (62.6\%) of the household heads were male. The biggest age group of the household heads was the 40 to 49 years group (21.9\%) followed by the 30 to 39 years group (20.5\%) and then the 50 to 59 year group $(20.0 \%)$. These figures also indicate that over seven out of 10 household heads $(72.5 \%)$ were between 20 to 59 years of age. A slight majority $(53.2 \%)$ of the household heads were married at the time of the survey, either in monogamous or polygamous unions; the vast majority were monogamous unions. Consensual marriage-type arrangements were the second most popular marital arrangement, tying for second place with widowed status.

In terms of formal educational attainment, about one out of the five (20.2\%) of the household heads had never been to school. Close to one-third of the household heads (32.6\%) had completed junior secondary school or its equivalent. Three out of one hundred household heads had some form of adult education to enable them to read and write in their local languages and/or English. About 18.5\% of the household heads had completed six years of primary school, $16.2 \%$ had some years of primary school while $4 \%$ had completed senior high school. The proportions of heads that had completed post-secondary technical school and university were $3.2 \%$ and $2.3 \%$, respectively.

The dominant religion affiliation was Christianity. Almost seven out 10 (69.7\%) of the household heads were Christians (the four sub-groups are shown in Table 1). The second most popular religious group was adherents of Traditional African Religions, who believed in a Supreme Being or God, and also communicated with extra-sensory or supra-normal deities (20.6\%). About 5.6\% of the household heads were atheists; four percent of the heads were Muslims.

In terms of ethnicity, the biggest group was Ewes. Almost three-quarters (74.9\%) of the household heads were Ewes. The next largest group was Gurmas; about $10.7 \%$ of the household heads were Gurmas. The third largest group of household heads was Guans who constituted $10 \%$ of the household heads. The remaining six broad ethnic groups in Ghana (Akans, Dangme/Ga, Grusi, Mole-Dagbani, Mande, and All others citizens originating from outside Ghana) represented only $4.4 \%$ of the household heads.

Table 2 provides a summary of the socio-economic characteristics of the sampled households using average and range figures. The average age of the household heads was 49.5 years with a range from 17 to 99 . The number of years of formal schooling acquisition of the household heads was 6.1 years with the range of zero to 15 years. Almost eight out of ten (78\%) of the household heads had ever attended school. The average household size was 4.3 with a range of 1 to 24 . About $56 \%$ of the households owned their own houses or dwelling premises. 
Table 1. Summary of socio-economic characteristics of the sampled rural households in the Volta Region of Ghana based on frequency analysis for groups

\begin{tabular}{|c|c|}
\hline Socio-Economic Characteristic of Household Head & Percentage \\
\hline \multicolumn{2}{|l|}{ Sex of Household Head } \\
\hline Male & 62.6 \\
\hline Female & 37.4 \\
\hline \multicolumn{2}{|l|}{ Age Group of Household Head } \\
\hline 15 to 19 & 0.4 \\
\hline 20 to 29 & 10.1 \\
\hline 30 to 39 & 20.5 \\
\hline 40 to 49 & 21.9 \\
\hline 50 to 59 & 20.0 \\
\hline 60 to 69 & 11.9 \\
\hline 70 to 79 & 10.5 \\
\hline 80 and above & 4.7 \\
\hline \multicolumn{2}{|l|}{ Marital Status of Household Head as at the Time of the Survey } \\
\hline Currently Married Monogamous & 47.6 \\
\hline Currently Married Polygamous & 5.6 \\
\hline Single & 4.3 \\
\hline Divorced/Separated & 10.5 \\
\hline Widowed & 16.0 \\
\hline Consensual Marriage and Flexible Unions & 16.0 \\
\hline \multicolumn{2}{|l|}{ Level of Formal Educational Attainment of Household Head } \\
\hline None/No Schooling & 20.2 \\
\hline Some years of primary school & 16.2 \\
\hline Completed all six years of primary school & 18.5 \\
\hline Completed junior high school of its Middle School equivalent & 32.6 \\
\hline Completed senior high school & 4.0 \\
\hline Completed post-secondary technical or vocational institute & 3.2 \\
\hline Completed university or higher & 2.3 \\
\hline Adult education & 3.0 \\
\hline \multicolumn{2}{|l|}{ Acquired Technical Education } \\
\hline Yes & 3.2 \\
\hline No & 96.8 \\
\hline \multicolumn{2}{|l|}{ Religious Affiliation of Household Head } \\
\hline No religion/atheists/agnostics & 5.6 \\
\hline Roman Catholic & 13.8 \\
\hline Protestant & 21.5 \\
\hline Pentecostal/ Charismatic & 29.1 \\
\hline Other Christians & 15.3 \\
\hline
\end{tabular}




\begin{tabular}{ll}
\hline Islam & 4.0 \\
\hline Adherents of African Traditional Religions & 20.6 \\
\hline Others & 0.1 \\
\hline Broad Ethnic Origin of Household Head & 3.1 \\
\hline Akan & 74.9 \\
\hline Ewe & 10.0 \\
\hline Guan & 10.7 \\
\hline Gurma & 0.4 \\
\hline Mole-Dagbani & 0.7 \\
\hline All other broad ethnic groups originating from Ghana (Dangme/Ga, Grusi, Mande) & 0.1 \\
\hline Other groups originating from outside Ghana (Hausa, Fulani, Zabrama) & \\
\hline
\end{tabular}

Table 2. Summary of socio-economic characteristics of the sampled rural households in the Volta Region of Ghana based on average and range figures

\begin{tabular}{llll}
\hline Item & Mean & Standard deviation & Range \\
\hline Age of the household head (years) & 49.5 & 16.46 & 17 to 99 \\
\hline $\begin{array}{l}\text { Number of years of formal schooling or education of the household } \\
\text { head (percent) }\end{array}$ & 6.1 & 4.61 & 0 to 15 \\
\hline Proportion of household heads ever attended school (percent) & 78.0 & 0.42 & 0 to 100 \\
\hline Ownership of house (percent) & 56.0 & 50.0 & 0 to 100 \\
\hline Number of people in the household (household size) & 4.31 & 2.97 & 1 to 24 \\
\hline Household connected to electricity grid (percent) & 58.0 & 49.0 & 0 to 100 \\
\hline Ownership of mobile phone (percent) & 35.2 & 47.8 & 0 to 100 \\
\hline
\end{tabular}

\subsection{Results of Analysis of Income-Generating Sources of Households}

The average number of broad income-based activities (NIBA) was 2.9, roughly equal to three broad income-generating activities undertaken by households. The overall diversification measure, SI averaged 0.342 (34.2\%) with a range from zero to 0.77 (refer to Table 3 ). In terms of the popularity of the income-based activities, Table 3 indicates that the most popular was rental income; $92.4 \%$ of households received some form of rental income. This was due to the GLSS reporting format that considered owner-occupied dwelling as a form of income. About five out of nine $(56.0 \%)$ of the households owned their dwelling premises (refer to Table 2). The next popular source of income was due to agriculture (both crop and livestock production); slightly over two-thirds (67.1\%) of rural households engaged in various agricultural-related activities.

The biggest source of the total household income was due to non-farm businesses which accounted for about $31.3 \%$ of total income. This was followed by agricultural production, which accounted for $23.3 \%$ of total income (refer to Table 4). Wage-based income accounted for slightly over one-sixth (17.0\%) of total household income and was the third biggest source of income. Though the most popular source, rental income only accounted for $15.9 \%$ of total household income. Remittances were the fifth biggest source of income and accounted for about $10.6 \%$ of total household income. All other activities accounted for only $1.9 \%$ of total household income. 
Table 3. The sources of incomes received by sampled rural households in the Volta Region of Ghana using frequency analysis for the specific income-generating activities

\begin{tabular}{lc}
\hline Item & Value \\
\hline Number of income-based activities, NIBA & 2.9 \\
\hline Overall measure of diversification: SI (Mean Value) & $34.2 \%$ \\
\hline $\begin{array}{l}\text { Household heads who received income from remittances as a proportion of the total number of } \\
\text { sampled respondents }\end{array}$ & $44.6 \%$ \\
\hline $\begin{array}{l}\text { Household heads who received income from renting a property as a proportion of the total number of } \\
\text { sampled respondents (including imputed owner-occupied housing) }\end{array}$ & $92.4 \%$ \\
\hline $\begin{array}{l}\text { Household heads who received income from wages as a proportion of the total number of sampled } \\
\text { respondents }\end{array}$ & $28.1 \%$ \\
\hline $\begin{array}{l}\text { Household heads who received income from non-farm business sources as a proportion of the total } \\
\text { number of sampled respondents }\end{array}$ & $48.9 \%$ \\
\hline $\begin{array}{l}\text { Household heads who received income from all other types of non-agricultural incomes as a proportion } \\
\text { of the total number of sampled respondents }\end{array}$ & $7.8 \%$ \\
\hline $\begin{array}{l}\text { Households who earned income from agricultural production (both crop production and livestock) as a } \\
\text { proportion of all sampled households }\end{array}$ & $67.1 \%$ \\
\hline
\end{tabular}

Table 4. The shares of the total household income attributable to the six broad income-based activities for the sampled rural households in the Volta Region of Ghana

\begin{tabular}{ll}
\hline Income Source & Percentage of Total Household Income \\
\hline Remittances received by the household head & 10.6 \\
\hline Rental property income belonging to household head & 15.9 \\
\hline Wage-based income earned by household head & 17.0 \\
\hline Non-farm business income earned by the household head & 31.3 \\
\hline All other sources of income earned by the household head & 1.9 \\
\hline Household agricultural production & 23.3 \\
\hline Total household income & 100.0 \\
\hline
\end{tabular}

The GSS upper poverty line (or poverty line) was 1760.80 Ghana cedis per adult person equivalent per year or 4.82 Ghana cedis per person per day. The GSS lower poverty line (extreme poverty) was 982.2 Ghana cedis per adult person equivalent per year or 2.69 Ghana cedis per adult person equivalent per day (GSS, 2018, pp. 8-9). The lower poverty line measured as the amount of money that would allow an adult householder to purchase food items necessary to acquire 2,900 calories of energy per day. The proportions of poor people in the region were computed and are presented in Table 5 for all the rural households and also for the different socio-economic groups. About $30.2 \%$ of the rural householders in the Volta Region were classified as poor, earning incomes below the minimum daily average benchmark of 4.82 Ghana cedis per adult equivalent per day. Gurma-headed households had the highest poverty figure of an average of $44.6 \%$ meaning that almost nine out 20 Gurma-headed households were poor. The next worst group was the Muslims group; 38.9\% of Muslim householders were poor. Adherents of Traditional African Religions fared slightly better with $36.4 \%$ poverty rate. Ewe-headed households had the lowest poverty figure of $27.9 \%$.

Based on the World Bank (2015) definition of extreme poverty, which was equivalent to 1.96 US dollars per adult person per day, (or 8.22 Ghana cedis per adult person per day for the October 2016 to October 2017 period), the average poverty rate was $64.1 \%$; for the various structural groups this poverty rate ranged from $61.2 \%$ for Christian-headed household to $73.9 \%$ for Gurma-headed households. Table 6 is a summary of information on the proportions of various groups classified as absolutely poor with the adult householder earning less than 2.69 Ghana 
cedis per day, which was not adequate to get the minimum daily energy intake of 2,900 calories. On average, $7.8 \%$ of rural adult householders in the region were absolutely poor. The structural group with the largest proportion of absolutely poor was Gurma-headed households, followed by Guans, and adherents of Traditional African Religions. Muslim-headed households had the lowest proportion of people who were absolutely poor.

Table 5. The proportions of the rural households considered to be poor classified by both GSS GLSS7 and World Bank poverty lines and according to ethnic and religious groups for the Volta Region of Ghana (\%)

\begin{tabular}{lll}
\hline Item & $\begin{array}{l}\text { GSS-Classified } \\
\text { Poor }\end{array}$ & $\begin{array}{l}\text { World } \\
\text { Bank-Classified } \\
\text { Poor }\end{array}$ \\
\hline $\begin{array}{l}\text { Proportion of Ewe-Headed Households Considered } \\
\text { Poor }\end{array}$ & 27.9 & 62.3 \\
\hline $\begin{array}{l}\text { Proportion of Guan-Headed Households Considered } \\
\text { Poor }\end{array}$ & 26.7 & 65.1 \\
\hline $\begin{array}{l}\text { Proportion of Gurma-Headed Households Considered } \\
\text { Poor }\end{array}$ & 44.6 & 73.9 \\
\hline $\begin{array}{l}\text { Proportion of African Traditional Religions } \\
\text { Adherent-Headed Households Considered Poor }\end{array}$ & 36.4 & 72.3 \\
\hline $\begin{array}{l}\text { Proportion of Christian-Headed Households Considered } \\
\text { Poor }\end{array}$ & 27.5 & 61.2 \\
\hline $\begin{array}{l}\text { Proportion of Islam-Headed Households Considered } \\
\text { Poor }\end{array}$ & 38.9 & 66.7 \\
\hline Proportion of the Total Population Considered Poor & 30.2 & 64.1 \\
\hline
\end{tabular}

Table 6. The proportions of the rural households considered to be extremely-poor (absolutely-poor) classified by ethnic and religious groups using GSS GLSS7 poverty line figure for the Volta Region (\%)

\begin{tabular}{ll}
\hline Item & $\begin{array}{l}\text { Mean GSS-Classified } \\
\text { Extremely Poor }\end{array}$ \\
\hline Proportion of Ewe-Headed Household Considered Extremely Poor & 5.6 \\
\hline Proportion of Guan-Headed Household Considered Extremely Poor & 12.8 \\
\hline Proportion of Gurma-Headed Households Considered Extremely Poor & 16.3 \\
\hline $\begin{array}{l}\text { Proportion of African Traditional Religions Adherent-Headed Households Considered } \\
\text { Extremely Poor }\end{array}$ & 10.9 \\
\hline Proportion of Christian-Headed Households Considered Extremely Poor & 6.9 \\
\hline Proportion of Islam-Headed Households Considered Extremely Poor & 5.6 \\
\hline Proportion of the Total Population Considered Extremely Poor & 7.8 \\
\hline
\end{tabular}

\subsection{Results of the Analysis of the Determinants of Household Income Diversification}

Table 7 summarizes the results of the regression analysis of the factors influencing the overall income diversification, as measured by SI. The highly-significant SIGMA parameter value indicated that the Tobit model, involving the use of a maximum likelihood procedure for its estimation, was more appropriate for this analysis as compared to the ordinary least squares (OLS) method. Only five out of the 22 independent variables had parameters which were statistically significant in influencing SI. These were (1) HHAGE, (2) HHSEX, (3) HHSIZE, (4) EDJSS and (5) REMITTANCE. The positive drivers of SI were the age of the household head, the size of the household, household head having junior secondary school qualifications, and the amount of remittance received by the household head. Households headed by males had significantly lower income diversification than those headed by females. 
Table 8 is a summary of the results of the regression analysis of factors affecting the count index measure of income diversification, NIBA. The power of this model was modest as indicated by the $\mathrm{R}^{2}$ of $21.1 \%$. A total of 15 out of the 24 independent variables were statistically significant in influencing NIBA. The age of the household head influenced NIBA in a cubic-form fashion (S-shaped curve) with declining values of NIBA observed at relatively young ages, between 17 to 31 years as shown in Figure 1, possibility due to schooling and educational activities. From 31 years to 74 years, NIBA increased with increasing age of the household head. Beyond 74 years, NIBA actually declined.

The revealing life-cycle NIBA versus age of the household head curve, illustrated in Figure 1, suggested that NIBA was really a long-term measure of income diversification. Given that SI measured the income diversification within one production year, based on the survey, SI was technically a short-term measure of income diversification, reflecting the situational realities of household incomes within a particular production year.

Table 7. Results of the Tobit multiple regression analysis of the factors influencing the overall household income diversification in the Volta Region based on the GLSS7 data compiled in 2017. The dependent variable is the Simpson index (SI).

\begin{tabular}{llll}
\hline Explanatory Variable & Parameter Estimate & Student t Test Value & $\begin{array}{l}\text { Significance } \\
\text { Probability }\end{array}$ \\
\hline INTERCEPT & 0.109 & 2.045 & $0.041^{* *}$ \\
\hline HHAGE & 0.003 & 5.129 & $0.000^{* * *}$ \\
\hline HHSEX & -0.042 & 2.159 & $0.031^{* *}$ \\
\hline CMARRIED & 0.012 & 0.598 & 0.550 \\
\hline HHDISABLED & 0.015 & -0.492 & 0.623 \\
\hline HHSIZE & 0.022 & 3.246 & $0.001^{* * *}$ \\
\hline EDPRIMARY & 0.034 & 1.514 & 0.130 \\
\hline EDJSS & 0.051 & 2.006 & $0.045^{* *}$ \\
\hline EDSSS & 0.041 & 0.915 & 0.360 \\
\hline EDPSTECHNICAL & -0.001 & -0.024 & 0.981 \\
\hline EDUNIVERSITY & -0.026 & -0.510 & 0.610 \\
\hline EDADULT & 0.054 & 1.227 & 0.220 \\
\hline MPHONE & -0.0008 & -0.048 & 0.962 \\
\hline OWNHOUSE & 0.025 & 1.542 & 0.123 \\
\hline RENTALVALUE & 0.002 & 1.265 & 0.206 \\
\hline REMITTANCE & 0.003 & 3.987 & $0.000^{* * *}$ \\
\hline ELECTRICITYCON & -0.019 & -1.263 & 0.207 \\
\hline AFRITRADRELIGION & -0.024 & -0.738 & 0.460 \\
\hline CHRISTIAN & -0.022 & -0.744 & 0.457 \\
\hline ISLAM & -0.017 & -0.344 & 0.731 \\
\hline EWE & 0.017 & 0.611 & 0.541 \\
\hline GUAN & -0.002 & -0.064 & 0.949 \\
\hline GURMA & 0.018 & 0.511 & 0.609 \\
\hline SIGMA & 0.184 & 35.673 & \\
\hline & & & \\
\hline
\end{tabular}

Notes:

$* * * 1 \%$ level of significance, $* * 5 \%$ level of significance, $* 10 \%$ level of significance.

Sample size $=894$. Proportion of uncensored observations was $95.9 \%$. 


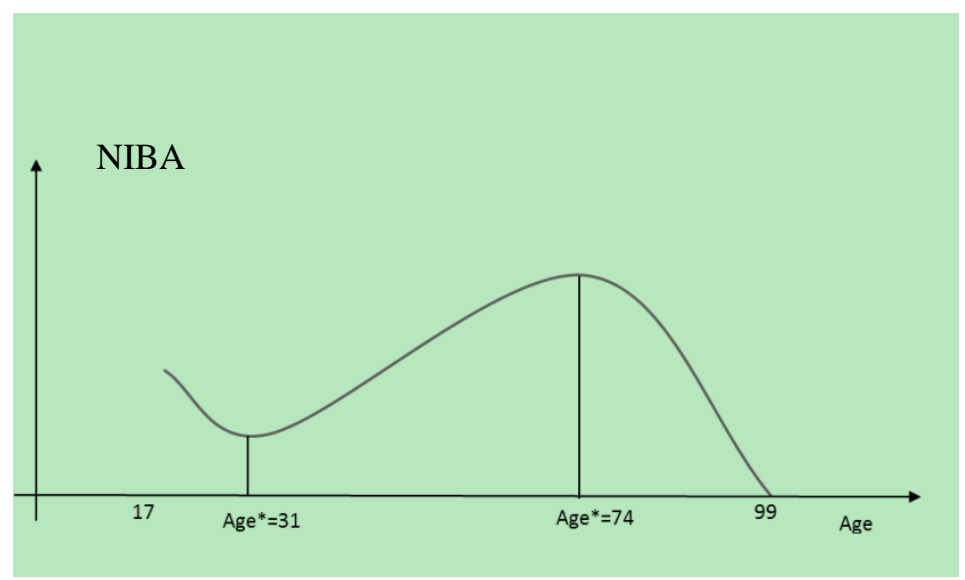

Figure 1. A graph of the relationship between the NIBA and age of household head

Table 8 also indicates that the positive drivers of NIBA included currently-married status of the household head, household size, acquisition of primary and secondary school formal educational qualifications, remittances, ownership of dwelling premises by the household, ownership of mobile phone and electricity connection to the household. All the six structural variables, related to religious preferences and ethnicity group classification, were not statistically significant, with the exception of the EWE ethnic variable. Similar to the SI effect, male-headed households had significantly lower NIBA than female-headed households. The two variables related to high educational attainment, post-secondary technical institute and university qualifications were not statistically-significant factors influencing NIBA. The statistical significance of the currently-married status of the household head in influencing NIBA reinforces our view that NIBA could be envisioned as a long-term measure of income diversification reflecting the life-cycle changes in terms of the acquisition of additional income-based activities of the household head over his/her lifetime, linked to changes reflecting marriage and old age (retirement). As shown in Table 7, SI was not influenced by the currently-married status of the household head suggesting once again that this particular index was more of a short-term measure of diversification reflecting the short-term changes implicit in the one production year data generated by the GLSS7.

Table 8. Results of the Poisson multiple regression analysis of the factors influencing the number of income-based activities (NIBA) of rural households in the Volta Region based on the GLSS7 data compiled in 2017. The dependent variable is NIBA.

\begin{tabular}{llll}
\hline Explanatory Variable & Parameter Estimate & Student t Test Value & $\begin{array}{l}\text { Significance } \\
\text { Probability }\end{array}$ \\
\hline INTERCEPT & 0.183 & 5.685 & $0.000^{* * *}$ \\
\hline HHAGE & -0.022 & -2.003 & $0.045^{* *}$ \\
\hline HHAGESQ & 0.0005 & 2.434 & $0.015^{* *}$ \\
\hline HHAGECUBIC & -0.000003 & -2.604 & $0.009^{* * *}$ \\
\hline HHSEX & -0.061 & -2.735 & $0.006^{* * *}$ \\
\hline CMARRIED & 0.050 & 2.188 & $0.029^{* *}$ \\
\hline HHDISABLED & -0.018 & -0.563 & 0.573 \\
\hline HHSIZEADULT & 0.051 & 6.508 & $0.000^{* * *}$ \\
\hline EDUPRIMARY & 0.083 & 3.148 & $0.002^{* * *}$ \\
\hline EDUJSS & 0.091 & 3.091 & $0.002^{* * *}$ \\
\hline EDUSSS & 0.096 & 1.828 & $0.068^{*}$ \\
\hline EDUPSTECHNICAL & 0.103 & 1.573 & 0.116 \\
\hline
\end{tabular}




\begin{tabular}{llll}
\hline EDUUNIVERSITY & 0.058 & 0.735 & 0.463 \\
\hline EDUADULT & 0.146 & 3.314 & $0.001^{* * *}$ \\
\hline MPHONE & 0.043 & 2.394 & $0.017^{* *}$ \\
\hline OWNHOUSE & 0.044 & 2.427 & $0.015^{* *}$ \\
\hline RENTALVALUE & 0.001 & 0.533 & 0.594 \\
\hline REMITTANCE & 0.005 & 5.233 & $0.000^{* * *}$ \\
\hline ELECTRICITYCON & 0.033 & 1.891 & $0.059^{*}$ \\
\hline AFRITRADRELIGION & -0.030 & -0.685 & 0.493 \\
\hline CHRISTIAN & -0.027 & -0.646 & 0.518 \\
\hline ISLAM & 0.014 & 0.221 & 0.825 \\
\hline EWE & 0.080 & 2.028 & $0.043^{* *}$ \\
\hline GUAN & 0.032 & 0.675 & 0.500 \\
\hline GURMA & -0.059 & -1.250 & 0.211 \\
\hline
\end{tabular}

\section{Notes:}

$* * * 1 \%$ level of significance, $* * 5 \%$ level of significance, $* 10 \%$ level of significance.

Sample size $=894$. $\mathrm{R}^{2}$ was $21.1 \%$.

The results of the multiple regression analysis of factors influencing per capita household economic welfare are reported in Table 9. The power of the model was quite good for a cross-sectional data-based equation with the $\mathrm{R}^{2}$ of 0.245 . The model was correctly specified based on the Ramsey Reset test with a p value of 0.748 well above the critical maximum $\mathrm{p}$ value of 0.10 used for this study. Further, there was no significant heteroscedasticity as measured by the Lagrange Multiplier test $\mathrm{p}$ value of 0.418 . The very low variance inflation factors for all the independent variables suggested the absence of any significant multicollinearity (refer to Table 9). The estimated model could therefore be used for further interpretative analysis

The results reported in Table 9 indicated that a curvilinear relationship (U-shaped curve) existed between per capita household economic welfare and SI. Differentiating the estimated equation with respect to SI revealed that the turning point at which overall income diversification would begin to lead to increased economic welfare was 0.492 $(49.2 \%)$. This is illustrated in Figure 2. This result suggested that income diversification would need to be at moderate to high levels to lead to improved household economic welfare.

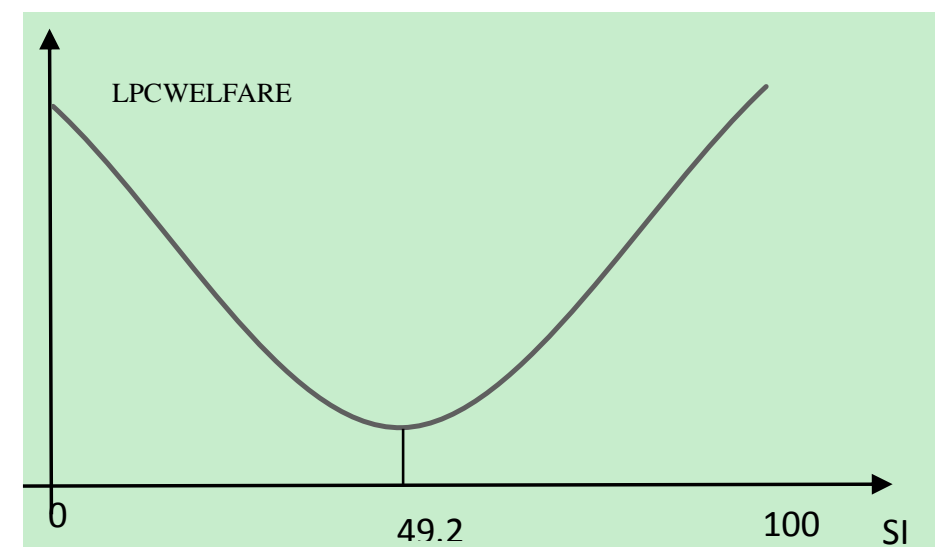

Figure 2. A Graph of the Relationship between the LPCWELFARE and SI 
Table 9. Results of the multiple regression analysis of the linkage between income diversification, as measured by SI, and household economic welfare of rural households in the Volta Region of Ghana using GLSS7 data.

Dependent variable is the natural logarithm of per capita economic welfare (LPCWELFARE)

\begin{tabular}{|c|c|c|c|c|c|}
\hline Explanatory Variable & $\begin{array}{l}\text { Unstandardised } \\
\text { Regression } \\
\text { Parameter Estimate }\end{array}$ & $\begin{array}{l}\text { Standardised } \\
\text { Regression } \\
\text { Parameter } \\
\text { Estimate }\end{array}$ & $\begin{array}{l}\text { Student } \\
\mathrm{T} \text { value }\end{array}$ & $\begin{array}{l}\text { Probability } \\
\text { Level of } \\
\text { Significance }\end{array}$ & $\begin{array}{l}\text { Variance } \\
\text { Inflation } \\
\text { Factor }\end{array}$ \\
\hline INTERCEPT & 3.072 & 0.000 & 20.738 & $0.000 * * *$ & 0.000 \\
\hline SI & -1.088 & -0.311 & -2.465 & $0.014 * *$ & 13.477 \\
\hline SISQUARED & 1.105 & 0.215 & 1.718 & $0.086^{*}$ & 13.267 \\
\hline HHAGEGROUP & -0.290 & -0.160 & -4.361 & $0.000 * * *$ & 1.138 \\
\hline LARGEHHSIZE & -0.409 & -0.273 & -6.997 & $0.000 * * *$ & 1.287 \\
\hline EDPRIMARY & -0.048 & -0.034 & -0.911 & 0.363 & 1.149 \\
\hline EDSSS & 0.094 & 0.027 & 0.754 & 0.451 & 1.074 \\
\hline EDPSTECHNICAL & 0.259 & 0.062 & 1.729 & $0.084 *$ & 1.073 \\
\hline EDUNIVERSITY & 0.609 & 0.145 & 4.099 & $0.000 * * *$ & 1.061 \\
\hline EDADULT & -0.190 & -0.049 & -1.368 & 0.172 & 1.079 \\
\hline LRENTALVALUE & 0.195 & 0.175 & 4.336 & $0.000 * * *$ & 1.374 \\
\hline ELECTRICITYCON & 0.255 & 0.185 & 4.971 & $0.000 * * *$ & 1.172 \\
\hline DISABLED & -0.321 & -0.116 & -2.005 & $0.045^{* *}$ & 2.826 \\
\hline DISABLED*CMARRIED & 0.331 & 0.085 & 1.729 & $0.084 *$ & 2.046 \\
\hline DISABLED*HOUSEOWN & 0.332 & 0.091 & 1.720 & $0.086^{*}$ & 2.361 \\
\hline AFRITRADRELIGION & 0.021 & 0.013 & 0.204 & 0.839 & 3.418 \\
\hline CHRISTIAN & 0.093 & 0.064 & 0.960 & 0.338 & 3.761 \\
\hline ISLAM & 0.137 & 0.036 & 0.850 & 0.396 & 1.523 \\
\hline EWE & 0.053 & 0.035 & 0.586 & 0.558 & 2.992 \\
\hline GUAN & -0.104 & -0.046 & -0.921 & 0.357 & 2.090 \\
\hline GURMA & -0.040 & -0.018 & -0.344 & 0.731 & 2.310 \\
\hline
\end{tabular}

Notes: $\mathrm{R}^{2} 0.245^{* *}$; Adjusted $\mathrm{R}^{2} 0.222^{* * * *}$

Probability significance level of Ramsey Reset Test for correct model specification

based on the null hypothesis of adequately-correct model specification 0.710

Probability significance level of the Lagrange Multiplier test of no heteroscedasticity

based on the null hypothesis of homoscedasticity or no heteroscedasticity 0.418

*** denotes statistical significance of the parameter at the $1 \%$ level.

** denotes statistical significance of the parameter at the $5 \%$ level.

* denotes statistical significance of the parameter at the $10 \%$ level.

Using the standardized estimates, SI was the most important independent variable affecting per capita household economic welfare. Other factors also significantly affected household economic welfare. Household heads aged 69 and above had lower economic welfare than those aged 68 and below. Large-sized households (greater than five) had lower per capita economic welfare than small-sized households. A numerical simulation exercise confirmed that five was the optimal household size, implying that a household with the head, spouse, and three dependents, would be the ideal household size that would ensure maximum economic welfare, assuming other things constant. 
High formal educational attainment of the household head, related to post-secondary technical school and university education, translated to increased household economic welfare. Similarly, rental value of the household dwelling and electricity connection to the household dwelling premises were positively associated with household welfare. While the disability status of the household head led to decreased economic welfare, the moderating effects on disability based on currently married status of the household head, and the ownership of dwellings by the household, both led to improved economic welfare of households headed by disabled people.

\section{Conclusions and Recommendations}

\subsection{Conclusions}

The study was primarily concerned with the establishment of factors influencing income diversification, and the linkage between income diversification and economic welfare of rural households in the Volta Region of Ghana. The analysis of the study was conducted with data from 894 randomly-selected households obtained from GLSS7, conducted over the period, October 2016 to October 2017. We used two measures for income diversification, an overall measure indicated by SI, and a count index, NIBA. The SI was influenced by the age of the household head, remittances received by the household, and the size of the household. For the second measure of diversification, NIBA, we established that the age of the household head influenced NIBA in a cubic fashion, similar to an S-shaped curve. Income diversification declined at very young ages from 17 to 31 years; it then increased from 31 years to 74 years, before declining after the latter age during the household head's advanced age and retirement period.

Given the established life-cycle-based age of the household head influences on NIBA, we suggest that NIBA could be regarded as a long-term measure of income diversification, while SI could be treated as a short-term measure of income diversification; the latter index's relies on the incomes generated just within one production year.

The positive drivers of NIBA included moderate levels of formal educational attainment, remittance, household size and electricity connection to the household. Income diversification influenced economic welfare only when used at moderate to high levels. Other factors, beyond income diversification, also improved household economic welfare. These other factors included the acquisition of either post-secondary technical school or university education by the household head, and electricity connection to the household. Households headed by disabled people had lower economic welfare as compared to households headed by able-bodied people. However, the economic welfare of disabled people improved with their currently-married status and ownership of a house.

\subsection{Policy Recommendations}

First of all, we established that moderate to high income diversification by rural households was a key factor for improved household economic welfare. Higher household income diversification in the region could be facilitated by expanded levels of opportunities that are created by State-intervention programmes and Community activities, such as those involved in the development of modern farmer market centres, improved infrastructure, and modern factories. We argue that large societal investments in the rural areas of the region could derail the activities of separatist groups, originating from the region, who have been advocating for a separate country from Ghana, sometimes using violent means. In September 2020, separatist groups launched surprise attacks on government facilities in the region, overrunning several police stations, resulting in injuries and deaths. Public assets and facilities were destroyed at Aveyime, Ho, Juapong and Mepe, from these attacks. A major driver of the militancy problem is the widespread poverty, plus a youthful population in the region, underemployed, who are easier to recruit by militant organizations.

Second, our study established the importance of post-secondary technical school qualifications acquired by household heads. Post-secondary school technical training qualifications are welfare-enhancing; however these qualifications have only been acquired by $3.2 \%$ of household heads in the rural parts of the region. Since 2017, the government of Ghana has implemented a policy of comprehensively-free senior secondary school education that encompasses not only free tuition, but also free boarding and lodging. The implementation of this programme has been difficult and fraught with several challenges partly due to the rapidly deteriorating financial position of the Ghanaian State.

A more efficient option is for the government to move away from the fully-free boarding and lodging system that favours well-to-do in society. The serious financial difficulties of the State, linked to a government budget deficit of $12 \%$ of GDP in 2020, and growing stock of national debts estimated to be $76.7 \%$ of GDP at the end of 2020 by the International Monetary Fund, require the government to implement a modified free senior secondary school system based on free-day-based secondary school education. This could be complemented with a free-day-based post-secondary technical and vocational educational system similar to the Australian Technical and Further 
Education (TAFE) System. The TAFE system has a two-track eligible choice system for post-secondary school education, with one track for technical and further education, and another track that leads directly to university training and education.

Third, we established that large household sizes were a significant determinant of low economic welfare and that the optimal household size that led to the maximum economic welfare was five - essentially made up of the household head, spouse, and three dependents. However, almost four of every five (79.8\%) rural households in the region had sizes greater than five mainly due to high birth rates. The high population growth rate in the region, and the country, as a whole, is linked to the poverty in rural areas. The discourse on family planning, common in the first three decades of the post-independence era, needs to be revisited by policymakers and political parties in Ghana.

\section{References}

Agyemang, B. A., Asuming-Brempong, S., \& Onumah, E. E. (2014). Determinants of income diversification of farm households in the Western region of Ghana. Quarterly Journal of International Agriculture, 53(1), 55-72.

Aked, J., Marks, N., Cordon, C., \& Thompson, S. (2008). Five ways to well-being: the evidence. London: New Economics Foundation.

Anaman, K. A., \& Bukari, G. A. (2019). Political economy analysis of the voter turnout and choices in national elections during the Ghana's fourth republican era, 1992 to 2016. Research in World Economy, 6, 28-44. https://doi.org/10.11114/aef.v6i3.4202

Anaman, K. A., \& Bukari, G. A. (2021). Voter turnouts in presidential elections in Ghana: a political economy analysis using district-level data. Applied Economics and Finance, 8, 13-31. https://doi.org/10.11114/aef.v8i1.5083

Anaman, K. A., \& Kassim, H. M. (2006). Marriage and female labour supply in Brunei Darussalam: a case study of urban women in Bandar Seri Begawan. The Journal of Socio-Economics, 35, 797-812. https://doi.org/10.1016/j.socec.2005.11.038

Andrew, F. M., \& Withey, S. B. (1976). Social indicators of well-being. New York and London: Plenum, 20(31), 696-717. https://doi.org/10.1007/978-1-4684-2253-5

Bellù, L. G., \& Liberati, P. (2005). Equivalence scales: subjective methods. Rome: Food and Agriculture Organization of the United Nations.

Buse, R. C., \& Salathe, L. E. (1978). Adult equivalent scales: an alternative approach. American Journal of Agricultural Economics, 60(3), 460-468. https://doi.org/10.2307/1239943

Cahn, M. (2002). Sustainable livelihoods approach: concept and practice. Massey, New Zealand: Massey University.

Carter, M. R. (1997). Technology and the social articulation of risk in West African agriculture. Economic Development and Cultural Change, 45(3), 557-590. https://doi.org/10.1086/452291

Chenery, H., \& Syrquin, M. (1975). Patterns of development 1950-1970. Washington: World Bank.

Davis, B., Winters, P., Carletto, G., Covarrubias, K., Quinones, E., Zezza, A., ... DiGiuseppe, S. (2007). Rural income generating activities: a cross-country comparison. ESA Working Paper No. 07-16, Rome: Food and Agriculture Organization. https://doi.org/10.2139/ssrn.3307433

Dedehouanou, S. F., \& McPeak, J. (2020). Diversify more or less? Household income generation strategies and food security in rural Nigeria. The Journal of Development Studies, 56(3), 560-577. https://doi.org/10.1080/00220388.2019.1585814

Ellis, F. (2000). Rural livelihoods and diversity in developing countries. Oxford: Oxford University Press.

Gecho, Y. (2017). Rural farm households' income diversification: The case of Wolaita Zone, Southern Ethiopia. Social Sciences, 6(2), 45-56. https://doi.org/10.11648/j.ss.20170602.12

Ghana Statistical Service (GSS). (2008). Ghana living standards survey (GLSS) round 5 report. Accra: GSS.

Ghana Statistical Service (GSS). (2013). 2010 National population and housing census: analytical report. Accra: GSS.

Ghana Statistical Service (GSS). (2014). Ghana living standards survey round 6 (GLSS 6): poverty profile in Ghana (2005-2013). Accra: GSS.

Ghana Statistical Service (GSS). (2015). Ghana poverty mapping report. Accra: GSS. 
Ghana Statistical Service (GSS). (2017). Ghana living standards survey round 7 final manual. Accra: GSS.

Ghana Statistical Service (GSS). (2018). Ghana living standards survey round 7 poverty trends in Ghana 2005-2017. Accra, GSS.

Ghana Statistical Service (GSS). (2020). Rebased 2013-2019 annual gross domestic product April 2020 edition. Accra: GSS.

Haggblade, S., Hazell, P., \& Reardon, T. (2010). The rural non-farm economy: prospects for growth and poverty reduction. World Development, 38(10), 1429-1441. https://doi.org/10.1016/j.worlddev.2009.06.008

Herfindahl, O. C. (1950). Concentration in the U.S. steel industry. New York: Columbia University.

Hirschman, A. O. (1945). National power and the structure of foreign trade. Berkeley: University of California Press.

Hoogeveen, J. G. M. (2002). Income risk, consumption security and the poor. Oxford Development Studies, 30(1), 105-121. https://doi.org/10.1080/136008101200114921

Kahn, R. L., \& Juster, F. T. (2002). Wellbeing: concepts and measures. Journal of Social Issues, 58(4), 627-644. https://doi.org/10.1111/1540-4560.00281

Loison, S. A. (2015). Rural livelihood diversification in Sub-Saharan Africa: a literature review. The Journal of Development Studies, 51(9), 1125-1138. https://doi.org/10.1080/00220388.2015.1046445

Narayan, D., Chambers, R., Shah, M. K., \& Petesch, P. (2000). Voices of the poor: crying out for change. New York: Oxford University Press for the World Bank. https://doi.org/10.1596/0-1952-1602-4

Omamo, S. W. (1998). Transport costs and smallholder cropping choices: An application to Siaya District, Kenya. American Journal of Agricultural Economics, 80(1), 116-123. https://doi.org/10.2307/3180274

Pollard, E. L., \& Lee, P. D. (2003). Child well-being: a systematic review of the literature. Social Indicators Research, 61(1), 59-78. https://doi.org/10.1023/A:1021284215801

Rønning, L., \& Kolvereid, L. (2006). Income diversification in Norwegian farm households: Reassessing pluriactivity. International Small Business Journal, 24(4), 405-420. https://doi.org/10.1177/0266242606065510

Salifu, G. A. N., \& Anaman, K. A. (2019). A political economy analysis of income diversification activities of rural households in the Northern region of Ghana. Applied Economics and Finance, 6(5), 10-34. https://doi.org/10.11114/aef.v6i5.4405

Salifu, G. A.-N. (2019). The political economy dynamics of rural household income diversification: a review of the international literature. Research in World Economy, 10(3), 273-290. https://doi.org/10.5430/rwe.v10n3p273

Scoones, I. (1998). Sustainable rural livelihoods: a framework for analysis. Sussex, Great Britain: Institute of Development Studies, University of Sussex.

Simpson, E. H. (1949). Measurement of diversity. Nature, 163(4148), 688-688. https://doi.org/10.1038/163688a0

Sultana, N., Hossain, E., \& Islam, K. (2015). Income diversification and household well-being: a case study in rural areas of Bangladesh. Int. J. Bus. Econ. Res., 4(3), 172-179. https://doi.org/10.11648/j.ijber.20150403.20

Tobin, J. (1958). Estimation of relationships for limited dependent variables. Econometrica, 26, 24-36. https://doi.org/10.2307/1907382

United Nations Development Programme (UNDP). (2020). Human development 2020 Ghana. Accra: UNDP. Retrieved 18 December 2020, from http://www.hdr.undp.org/sites/all/themes/hdr_theme/country-notes/GHA.pdf

World Bank. (2015). The international poverty line. Retrieved September 21, 2020, from https://www.worldbank.org/en/programs/icp/brief/poverty-line

\section{Copyrights}

Copyright for this article is retained by the author(s), with first publication rights granted to the journal.

This is an open-access article distributed under the terms and conditions of the Creative Commons Attribution license (http://creativecommons.org/licenses/by/4.0/). 